\title{
Pengaruh Terapi Bermain Puzzle Terhadap Perkembangan Motorik Halus Anak Prasekolah : Literature Review
}

\author{
Luluk Erni Slamet Widiawati ${ }^{1 *}$, Wiwiek Natalya² \\ ${ }^{1,2}$ Program Studi Sarjana Keperawatan, Universitas Muhammadiyah Pekajangan Pekalongan, \\ Indonesia \\ *email: Lulukerni270@gmail.com
}

\begin{abstract}
In Indonesia, abaut $16 \%$ of children under five year's experience developmental delays in fine motor skills. A lack of stimulation causes the delay by the playing media. A Puzzle game is one of the games, which is beneficial to stimulate fine motor skills To find out the effect of puzzle play therapy on the fine motor development of preschool children. A literature review of Quasy Eksperiment studies was used. The searching prpces for articles using the PubMed, Garuda Portal, and Google Schoolar database. Articles were selected that matched the inclusion criteria and appraised using DISCREN instrument. There were five articles included in this study. Two studies used the Denver II to measure fine motor skills, Whereas three used the KPSP instrument ( Indonesia child developmental and monitoring screening). Those studies were analyzed by using either the Wilcoxon test or t-test. All studies concluded a similisr result thst puzzle play therapy has a significant effect on preschool children's motor development. This study found the effect of puzzle games on the fine motor development of preschool children.
\end{abstract}

Keywords: Puzzle Play Therapy, fine motor development, Preschoolers

\begin{abstract}
Abstrak
Di Indonesia, sekitar $16 \%$ anak balita mengalami keterlambatan perkembangan motorik halus. Kurangnya stimulasi menyebabkan penundaan oleh media bermain. Game Puzzle merupakan salah satu game yang bermanfaat untuk merangsang motorik halus. Mengetahui pengaruh terapi bermain puzzle terhadap perkembangan motorik halus anak prasekolah. Tinjauan literatur studi Quasy Eksperiment digunakan. Proses pencarian artikel menggunakan database PubMed, Garuda Portal, dan Google Schoolar. Artikel dipilih yang sesuai dengan kriteria inklusi dan dinilai menggunakan instrumen DISCREN. Ada lima artikel yang termasuk dalam penelitian ini. Dua penelitian menggunakan Denver II untuk mengukur keterampilan motorik halus, sedangkan tiga penelitian menggunakan instrumen KPSP (penyaringan perkembangan dan pemantauan anak Indonesia). Studi-studi tersebut dianalisis dengan menggunakan uji Wilcoxon atau uji-t. Semua penelitian menyimpulkan hasil yang serupa bahwa terapi bermain puzzle berpengaruh signifikan terhadap perkembangan motorik anak prasekolah. Penelitian ini menemukan pengaruh permainan puzzle terhadap perkembangan motorik halusanak prasekolah.n.
\end{abstract}

Kata kunci: Terapi bermain puzzle, perkembangan motorik halus, anak prasekolah.

\section{Pendahuluan}

Hasil data dari profil kesehatan Indonesia pada tahun 2014 bahwa jumlah anak prsekolah dengan usia 1-5 tahun sebanyak 19.388.791 jiwa sekitar $16 \%$ usia dibawah 5 tahun anak Indonesia mengalami keterlambatan perkembangan dalam motorik halus Menurut menurut World Health Organization (WHO) pada tahun 2016, mengungkapkan bahwa $43 \%$ anak di negara berkembang mengalami keterlambatan dalam perkembangan. Pada tahun 2017 diketahui bahwa tingkat perkembangan 


\section{Prosiding Seminar Nasional Kesehatan Lembaga Penelitian dan Pengabdian Masyarakat Universitas Muhammadiyah Pekajangan Pekalongan}

motorik halus anak usia prasekolah sekitar 5-19\% dari anak prasekolah mengalami keterlambatan (RISKESDAS, 2018). Permasalahan yang dihadapi dalam perkembangan kemampuan motorik halus misalnya kurangnya kesempatan untuk melakukan eksplorasi terhadap lingkungan dan alat bermainya. Namun sebaiknya selaku pendidik atau orang tua hendaknya mengetahui permasalahan dan solusi bagaimana meningkatkan kemampuan motorik halus pada anak.

Faktor penyebab keterlambatan motorik halus pada usia prasekolah di sebabkan karena sedikit rangsangan melalui media bermainnya. Salah satu media bermain yang berguna untuk meningkatkan perkembangan motorik halus yaitu permainan puzzle (Meidirisa et all.2015). Fenomena saat ini pada tahun pertama sering kali tenaga kesehatan dan orang tua lebih mefokuskan pada perkembangan motorik kasar saja padahal untuk mencapai perkembangan yang optimal motorik halus adalah dasar untuk perkembangan usia tahap selanjutnya gerak motorik halus juga dipengaruhi oleh stimulus alat bermainya salah satunya permainan puzzle (Ardena et.al 2015).

Menurut Meidirisa et all (2015), permainan puzzle merupakan suatu permainan yang komplek. Puzzle adalah permainan menyusun gambar yang sebelumnya diacak terlebih dahulu sehingga membentuk suatu bentuk yang utuh.(Muzamil, 2010). Puzzle diyakini dapat meningkatkan keterampilan motorik halus pada anak, melalui aktivitas bermain puzzle tanpa disadari anak-anak akan belajar secara aktif untuk menggunakan jari-jari tangannya untuk menyusun gambar yang tepat. Hasil penelitian yang dilakukan oleh Lilis (2018) tentang metode bermain puzzle sangat berpenngaruh pada perkembangan motorik halus anak usia prasekolah. Sebagian besar perkembangan anak usia prasekolah sebelum diberikan metode bermain puzzle adalah normal sebanyak 26 anak atau (59\%) dari 44 anak setelah diberikan metode bermain puzzle menjadi sebanyak 38 anak atau (86\%).

Perkembangan motorik halus yang baik menentukan anak untuk melakukan aktivitas yang baik misalnya, menyisir rambut, memasang tali sepatu, menulis, dan menagancing baju secara mandiri (Erni Yuliati, 2018)

\section{Metode}

Penelitian ini menggunakan metode literature review yaitu melakukan proses pencarian mendalam mengenaik infomarsi terpublikasi dalam suatu topik proses pencarian menggunakan data base scholar, PubMed dan Portal Garuda kata kunci yang dugunakan pada database scholar dengan kata kunci "playing therapy puzzle", " fine motor development", preschool children", dengan hasil yang diperoleh adalah 11 artikel yang di peroleh 3 artikel yang memenuhi kriteria inklusi data kedua dengan menggunakan pubmed dengan kata kunci seperti diatas. Didapatkan sesuai artikel 7 kemudian dilakukan identifikasi artikel sesuai kriteria inklusi sebanyak 1 artikel dan menggunakan database portal garuda yang telah diidentifikasi inklusi sebanyak 1 . Sehingga didapatkan dari keseluruhan database tersebut sebanyak 5 artikel.

\section{Hasil dan Pembahasan}

\section{Hasil}

1. Karakteristik Responden

Hasil analisis dari 5 artikel didapatkan sebanyak 83 responden, dari 83 responden sebanyak $6(7,2 \%)$ berusia 2 tahun, responden sebanyak $14(16,9 \%)$ 


\section{Prosiding Seminar Nasional Kesehatan \\ Lembaga Penelitian dan Pengabdian Masyarakat Universitas Muhammadiyah Pekajangan Pekalongan}

berusia 3 tahun, sebanyak $35(42,1 \%)$ responden berusia 4 tahun dan 28 $(33,7 \%)$ responden berusia 5 tahun. Hasil analisa data artikel yang di review pada karakteristik usia responden didapatkan hasil responden paling banyak berusia 4 tahun yaitu 35 (42,1\%) disajikan dalam bentuk tabel sebagai berikut :

Tabel 3.1 Distribusi Frekuensi Berdasarkan Karakteristik Usia

\begin{tabular}{|c|c|c|c|c|c|c|c|c|c|c|c|}
\hline \multirow{3}{*}{$\begin{array}{l}\text { Penulis/ } \\
\text { Tahun }\end{array}$} & \multirow[t]{3}{*}{ Jml. responden } & \multicolumn{8}{|c|}{ Tingkat Usia } & \multirow[t]{3}{*}{ Total } & \multirow[t]{3}{*}{$\%$} \\
\hline & & \multicolumn{2}{|c|}{2 Tahun } & \multicolumn{2}{|c|}{3 Tahun } & \multicolumn{2}{|c|}{4 Tahun } & \multicolumn{2}{|c|}{5 Tahun } & & \\
\hline & & $f$ & $\%$ & $f$ & $\%$ & $f$ & $\%$ & $f$ & $\%$ & & \\
\hline Tedty Rohaya & & & & & & & & & & & \\
\hline $\begin{array}{l}\text { Tinambunan } \\
(2020)\end{array}$ & 18 & 0 & 0 & 0 & 0 & 6 & 33,3 & 12 & 66,7 & 18 & 100 \\
\hline $\begin{array}{l}\text { Rahmi Novita } \\
\text { Yusuf (2017) }\end{array}$ & 17 & 0 & 0 & 4 & 23,5 & 10 & 58,9 & 3 & 17,6 & 17 & 100 \\
\hline $\begin{array}{l}\text { Erni Yuniati } \\
\text { (2018) }\end{array}$ & 17 & 0 & 0 & 0 & 0 & 12 & 70,6 & 5 & 29,4 & 17 & 100 \\
\hline $\begin{array}{l}\text { Panzilion } \\
\text { (2020) }\end{array}$ & 15 & 0 & 0 & 0 & 0 & 7 & 46,7 & 8 & 52,2 & 15 & 100 \\
\hline $\begin{array}{l}\text { Meity Mulya } \\
\text { Susanti (2017) }\end{array}$ & 16 & 6 & 37,5 & 10 & 62,5 & 0 & 0 & 0 & 0 & 16 & 0 \\
\hline
\end{tabular}

\section{Perkembangan motorik halus}

Tingkat perkembangan motorik halus anak prasekolah yang diukur dengan menggunakan instrumen Denver II

Dari hasil analisa data artikel yang di review, karakteristik responden tingkat perkembangan motorik halus yang diukur menggunakan instrumen Denver II. Dari kelima artikel terdapat 2 yang menggunakan instrumen Denver II untuk mengukur perkembangan motorik halus yaitu artikel 1 dan artikel 3. artikel 1 dengan hasil perkembangan motorik halus pada anak usia dini sebelum diberikan terapi bermain puzzle di PAUD Dahlia Godong memiliki distribusi frekuensi yang sama, yaitu tidak sesuai usia sebesar 8 responden (50\%) dan yang sesuai umur 8 responden (50\%). Setelah diberikan terapi bermain puzzle paling banyak sesuai usia 12 responden (75\%) dan tidak sesuai usia 4 responden (25\%). Hasil penelitian artikel 3 didapatkan sebelum dilakukan terapi bermain puzzle hasil motorik halusnya dalam kategori sedang sebanyak 11 responden $(64,7 \%)$ dan 6 responden $(35,3 \%)$ memiliki perkembangan motorik halus kategori rendah, kemudian setelah dilakukan terapi bermain puzzle didapatkan bahwa sebagian besar anak motorik halusnya dalam kriteria tinggi $11(64,7 \%)$ dan sangat tinggi 4 $(23,5 \%)$ dan $2(18 \%)$ responden memiliki perkembangan mototrik halus sedang.

Hasil analisa tingkat perkembangan motorik halus dengan menggunakan instrumen Denver II sebelum dan sesudah dilakukan terapi bermain puzzle disajikan dalam bentuk tabel sebagai berikut : 


\section{Prosiding Seminar Nasional Kesehatan \\ Lembaga Penelitian dan Pengabdian Masyarakat

Tabel 3.2 Tingkat Perkembangan Motorik Halus Anak Prasekolah Sebelum Dan Sesudah Dilakukan Terapi Bermain Puzzle Menggunakan Instrumen Denver II.

\begin{tabular}{cccccc}
\hline \multirow{2}{*}{ Penulis } & \multirow{2}{*}{ perkembangan } & \multicolumn{3}{c}{ pre } & \multicolumn{3}{c}{ Post } \\
\cline { 3 - 6 } & Sedang & 11 & 64,7 & 2 & 11,8 \\
Erni Yuniati & Rendah & 6 & 35,3 & 0 & 0 \\
2018 & Tinggi & 0 & 0 & 11 & 64,7 \\
$\mathrm{~N}=17$ & Sangat tinggi & 0 & 0 & 4 & 23,5 \\
\hline Total & & 17 & 100 & 17 & 100 \\
\hline Meity Mulya Susanti & Tidak sesuai & 8 & 50 & 4 & 25 \\
$\mathrm{~N}=17$ & sesuai & 8 & 50 & 12 & 75 \\
\hline Total & & 16 & 100 & 16 & 100 \\
\hline
\end{tabular}

Tingkat perkembangan motorik halus anak prasekolah yang diukur dengan instrumen KPSP

Hasil analisa data artikel yang di review tingkat perkembangan motorik halus menggunakan KPSP. Kelima artikel terdapat 3 yang menggunakan instrumen KPSP yaitu artikel 2 , artikel 4 dan artikel 1.

Dari data artikel 2 menyebutkan perkembangan motorik halus anak balita sebelum dilakukan terapi bermain puzzle memiliki kategori meragukan sebanyak $13(76 \%)$ dan normal sebanyak 4 (24\%), setelah dilakukan terapi bermain puzzle tingkat perkembangan sesuai usia sebanyak $17(100 \%)$, sedangkan hasil penelitian artikel 4 menyebutkan sebelum dilakukan terapi bermain puzzle terdapat $8(53,3 \%)$ responden dengan motorik menyimpang dan setelah dilakukan terapi bermain puzzle $15 \quad(100 \%)$ responden mengalami peningkatan perkembangan motorik halus dengan kategori normal. Adapun artikel 1 yang menggunakan instrumen KPSP yaitu dengan cara observasi langsung dan didapatkan hasil sebelum dilakukan terapi bermain puzzle dalam kategori normal sebanyak 6 (33,3\%) dan meragukan $12(66,7 \%)$, setelah dilakukan terapi bermain puzzle, didapatkan hasil perkembangan dalam kategori normal $13(72,2 \%)$ dan meragukan 5 (27,8\%).. Hasil analisa data tingkat perkembangan motorik halus dengan menggunakan instrumen KPSP sesudah dilakukan terapi bermain puzzle disajikan dalam bentuk tabel sebagai berikut :

Tabel 3.3 Tingkat Perkembangan Motorik Halus Anak Prasekolah Sebelum Dan Sesudah Dilakukan Terapi Bermain Puzzle Menggunakan Instrumen KPSP.

\begin{tabular}{cccccc}
\hline \multirow{2}{*}{ Penulis } & \multirow{2}{*}{ Perkembangan } & \multicolumn{3}{c}{ pre } & \multicolumn{3}{c}{ Post } \\
\cline { 3 - 6 } & Normal & $\mathrm{f}$ & $\%$ & $\mathrm{f}$ & $\%$ \\
\hline Panzilion & Meragukan & 7 & 0 & 15 & 0 \\
$\mathbf{N}=15$ & & 15 & 0 & 0 & 0 \\
\hline Total & Normal & 6 & 0 & 13 & 0 \\
\hline Tedty Rohaya & Meragukan & 12 & 0 & 5 & 0 \\
$\begin{array}{c}\text { N }=17 \\
\text { Total }\end{array}$ & & 18 & 0 & 18 & 0 \\
\hline Rahmi Novita Yusuf & Normal & 4 & 24 & 17 & 0 \\
2017 & Meragukan & 13 & 76 & 0 & 0 \\
\hline Notal & & 17 & 100 & 17 & 100 \\
\hline Total & & & & &
\end{tabular}




\section{Prosiding Seminar Nasional Kesehatan \\ Lembaga Penelitian dan Pengabdian Masyarakat Universitas Muhammadiyah Pekajangan Pekalongan}

3. Pengaruh terapi bermain puzzle terhadap anak prasekolah

Berdasarkan analisa kelima artikel dengan total 83 responden, dilihat perbedaan nilai mean pada pretest dan postest terapi bermain puzzle. dari kelima artikel terdapat 4 artikel yang menggunakan uji statistik Wilcoxon, yaitu artikel 5 dengan hasil $p$-value 0,046, artikel 2 dengan hasil $p$-value 0,002, artikel 1 dengan hasil $p$-value 0,000 dan artikel 4 dengan hasil $p$-value 0,001, dan artikel 3 dengan menggunakan uji statistik T-test dengan hasil $p$-value 0,0001 . Kedua jenis uji statistik tersebut didapatkan hasil $p$-value yang valid. Kedua uji statistik tersebut didapatkan hasil $p$-value yang valid dengan tujuan pada penelitian ini, yaitu ada pengaruh terapi bermain puzzle terhadap perkembangan motorik halus anak prasekolah dibuktikan dengan nilai $p$-value $<0,05$ artinya Ho ditolak Ha diterima. Nilai tersebut membuktikan adanya pengaruh motorik halus pada anak prasekolah sebelum dan sesudah diberikan terapi bermain puzzle.

Pengaruh terapi bermain puzzle terhadap perkembangan motorik halus pada anak prasekolah sebelum dan sesudah diberikan terapi bermain puzzle. Disajikan dalam tabel sebagai berikut :

Tabel 3.4 Hasil Analisis Sintesa Sebelum Dan Sesudah Dilakukan Intervensi Terapi Bermain Puzzle Terhadap Perkembangan Motorik Halus Anak Usia Prasekolah.

\begin{tabular}{|c|c|c|c|c|c|c|}
\hline \multirow[t]{2}{*}{ No } & \multirow[t]{2}{*}{ Peneliti } & \multirow[t]{2}{*}{ Uji hipotesis } & \multirow{2}{*}{$\begin{array}{c}\text { Jumlah } \\
\text { responde } \\
\mathrm{n}\end{array}$} & \multicolumn{2}{|c|}{$\begin{array}{c}\text { (Mean) } \\
\text { Perkembangan Motorik } \\
\text { Halus }\end{array}$} & \multirow[t]{2}{*}{$P$-value } \\
\hline & & & & Pre & Post & \\
\hline 1 & $\begin{array}{l}\text { Tedty Rohaya } \\
\text { Tinambunan (2017) }\end{array}$ & Wilcoxon & 18 & 32,17 & 53,06 & 0,000 \\
\hline 2 & $\begin{array}{l}\text { Rahmi Novita Yusuf } \\
\text { (2017) }\end{array}$ & Wilcoxon & 17 & 7,71 & 8,65 & 0,002 \\
\hline 3 & $\begin{array}{l}\text { Erni Yuniati } \\
(2018)\end{array}$ & T-test Paired & 17 & 3,35 & 1,88 & 0,0001 \\
\hline 4 & Panzilion (2020) & wilcoxon & 15 & 0,00 & 8,00 & 0,001 \\
\hline 5 & $\begin{array}{l}\text { Meity Mulya Susanti } \\
\text { (2017) }\end{array}$ & wilcoxon & 16 & 1,50 & 1,75 & 0,046 \\
\hline
\end{tabular}

\section{Pembahasan}

\section{Karakteristik responden}

Berdasarkan tabel 3.1, karakteristik usia responden didapatkan bahwa ratarata responden berusia 2-5 tahun. Menurut teori padila et. aL (2019) menyatakan perkembangan motorik halus pada usia prasekolah (3-5 tahun) motorik halus lebih terkoordinasi disbanding pada masa toldler (1-3), hal ini dikarenakan anak terus menerus belajar dari pengalaman dan permainan yang menstimulasi dengan menggukan media dan peralatan sesuai dengan usianya. Faktor yang 


\section{Prosiding Seminar Nasional Kesehatan $\mathbf{2 0 2 1}$ \\ Lembaga Penelitian dan Pengabdian Masyarakat Universitas Muhammadiyah Pekajangan Pekalongan}

mempengaruhi perkembangan anak usia prasekolah salah satunya adalah bermain. Bermain adalah cara yang paling berharga, melalui bermain anak akan menggunakan sensor motorik atau fungsionalnya (Wong, 2009).

2. Perkembangan motorik halus sebelum dan setelah dilakukan terapi bermain puzzle

Berdasarkan table 3.2 dan 3.3 pada tingkat perkembangan motorik halus anak prasekolah diperoleh hasil yang signifikan yaitu menurut penelitian Susanti MM, (2017) bahwa tingkat perkembangan motorik halus pada anak usia dini sebelum dilakukan terapi bermain puzzle dengan hasil tidak sesuai usia sebanyak 8 (50\%) responden dan sesudah diberikan terapi bermain puzzle paling banyak sesuai usia 12 (75\%) responden, tidak sesuai 4 (25\%) responden.

Pada kondisi ini perkembangan motorik halus sudah mulai meningkat karena sudah diberikan intervensi terapi bermain puzzle, perkembangan tersebut dapat dilihat dari gerak motorik halus anak usia 2-5tahun, yaitu anak dapat menyusun menara 4 kubus, meniru garis vertical dan menyusun menara 8 kubus.

Hasil penelitian ini sejalan dengan penalitian yang dilakukan oleh Yusuf RN, (2017) tentang pengaruh stimulasi bermain puzzle terhadap perkembangan morotik halus. Pada anak balita perkembangan atau gerakan motorik halus yang berkaitan dengan kegiatan meletakan atau menggenggam suatu objek dengan jari tangan. Tingkat perkembangan motorik halus anak berada pada kategori meragukan terdapat $13(76 \%)$ responden.

Hal ini juga terlihat dari hasil observasi pada Kuesioner Pra Skrining Perkembangan (KPSP) yaitu perkembangan motorik halus yang meragukan, terlihat bahwa anak masih belum dapat melakukan tindakan sesuai usianya seperti menyususn menara 6 kubus, meniru garis vertical dan mencontohgambar lingkaran.

Sejalan dengan penelitian Panzilion, (2020) menyebutkan bahwa sebelum dilakukan terapi bermain puzzle terdapat $8(53,3 \%)$ responden mengalami motorik halus menyimpang dan $7(46,7)$ meragukan, dan setelah dilakukan terapi bermain puzzle didapatkan hasil 15 responden mengalami perkembangan motorik halus normal atau sesuai usianya, terkait penyimpangan ketika anak di tes dengan pertanyaan mereka tidak bisa melakukan instruksi meletakan kertas alasannya karena anak belum mau, dan soal selanjutnya anak belum dapat menggambar lingkaran, menurut Murtining, (2018) motorik halus adalah gerakan yang merangsang otot-otot kecil, gerakan halus ini memerlukan koordinasi mata yang cermat semakin baik gerakan motorik halus sehingga membuat anak dapat berkreasi, gerakan ini dapat dilakukan dengan melalui kegiatan menyusun puzzle.

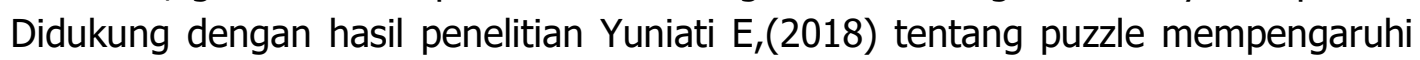
perkembangan motorik halus anak usia prasekolah di TK At-Taqwa mekarsari, cimahi didapatkan hasil bahwa sebagian besar anak motorik halusnya dalam kriteria tinggi setelah dilakukan terapi bermain puzzle. 


\section{Prosiding Seminar Nasional Kesehatan $\mid 2021$ Lembaga Penelitian dan Pengabdian Masyarakat Universitas Muhammadiyah Pekajangan Pekalongan}

3. Pengaruh terapi bermain puzzle terhadap perkembangan motorik halus anak prasekolah

Berdasarkan table 3.4 pengaruh terapi bermain puzzle terhadap perkembangan motorik halus anak prasekolah diperoleh bahwa ada pengaruh terapi bermain puzzle terhadap perkembangan motorik halus anak prasekolah, sejalan dengan penelitian Medirisa et all (2015), tentang Pengaruh Pemberian Stimulus Bermain Puzzle Terhadap Perkembangan Motorik Halus Anak Usia 4-6 Tahun Di Taman Kanak-Kanak Aisyiyah Krasak, Teras, Boyolali, menunjukkan bahwa ada pengaruh permainan edukatif puzzle terhadap perkembangan motorik halus anak. Penelitian dilakukan selama 6 minggu (1,5 bulan).

Hasil penelitian ini sejalan dengan hasil penelitian Tinambunan TR, (2020) tentang efektifitas alat permainan edukatif jenis puzzle terhadap perkembangan motorik halus pada anak usia 4-5 tahun menyatakan bahwa terdapat pengaruh permainan edukatif puzzle terhadap motorik halus anak usia 4-5 tahun, Hasil penelitian ini didukung oleh Yustisia, (2013), menjelaskan bahwa puzzle dapat meningkatkan keterampilan motorik halus merupakan kemampuan yang berhubungan dengan otot-otot kecil, terutama tangan dan jari-jari tangan dan melatih koordinasi mata dan tangan. Melalui aktivitas bermain puzzle, tanpa disadari anak akan belajar secara aktif untuk menggunakan jari-jari tangannya untuk menyusun gambar yang tepat.

Hasil penelitian ini juga selaras dengan penelitian Yusuf RN, (2017) yang menjelaskan bahwa terdapat pengaruh bermain puzzle terhadap perkembangan motorik halus anak. Hal ini dikarenakan permainan puzzle merupakan salah satu bentuk stimulus dan ketika diberi stimulus permainan puzzle anak tersebut memperhatikan sehingga dapat melatih kerja jari-jemari anak yang dikoordinasikan dengan kerja otak dalam menyusun kepingan-kepingan, sehingga anak menjadi terlatih dan secara tidak langsung hal ini dapat meningkatkan kemampuan motorik halus anak. Hasil penelitian ini hampir sama dengan penelitian Maghfuroh, (2018) tentang pengaruh penggunaan alat permainan metode bermain puzzle berpengaruh pada perkembangan motorik halus anak usia prasekolah di TK. Surya Baru Desa Plosowahyu Lamongan ditemukan hasil sebelum diberikan terapi bermain dengan mean 88,4\%. Ada pengaruh penggunaan alat permainan metode bermain dengan perkembangan motorik halus anak dengan $\mathrm{p}$-value $=0,001$.

Selain itu penelitian ini sejalan dengan penelitian Yuniati, E (2018) Puzzle Mempengaruhi Perkembangan Motorik Halus Anak Usia Prasekolah di TK At Taqwa Mekarsari Cimahi ditemukan hasil mean sesudah 1,88. Ada pengaruh permainan puzzle dengan perkembangan motorik halus pada anak dengan $p$-value $=0,0001$. Metode Bermain Puzzle berpengaruh pada Perkembangan Motorik Halus Anak Usia Prasekolah, sebab bermain puzzle dapat mengkoordinasi gerak mata dan tangan anak, dengan itu tanpa mereka sadari motorik halus mereka terus terlatih dan berkembang dengan bagus. Selain itu, ketika mereka bermain puzzle anak dapat berlatih untuk mengenal bentuk dan bagaimana mereka mengisi ruang kosong dimana potongan-potongan tersebut di perlukan. Hasil penelitian ini hampir sama dengan penelitian Maghfuroh, (2018) ditemukan hasil ada perbedaan sebelum dan 


\section{Prosiding Seminar Nasional Kesehatan Lembaga Penelitian dan Pengabdian Masyarakat Universitas Muhammadiyah Pekajangan Pekalongan}

sesudah diberikan terapi bermain puzzle ditemukan selisih mean 4,6 . Setelah dilakukan uji statistik paired samples T-test didapatkan nilai $p$-value $(0,002)<a$ 0,05 . Maka terdapat pengaruh penggunaan alat permainan metode bermain puzzle berpengaruh pada perkembangan motorik halus anak usia prasekolah ditemukan hasil sebelum diberikan terapi bermain puzzle. Berdasarkan uraian diatas dapat diartikan bahwa bermain puzzle merupakan media bermain sederhana yang dimainkan secara bongkar pasang yang membutuhkan ketelitian, karena anak dilatih untuk dapat memusatkan pikiran agar dapat berkonsentrasi, selain itu dengan bermain puzzle anak belajar tentang konsep bentuk, warna, ukuran dan jumlah yang dapat membantu mengembangkan kemampuan motorik halus anak dengan melibatkan koordinasi mata dan tangan serta melatih otot-otot jari tangan.

\section{Kesimpulan}

Berdasarkan usia responden terbanyak berusia 4 tahun sebanyak 35 responden dengan presentase $(42,1 \%)$.

Berdasarkan Literature review dari kelima artikel didapatkan hasil bahwa ada peningkatan perkembangan motorik halus anak usia prasekolah diukur dengan menggunakan Denver II dan KPSP, di ketahui dengan kategori awal meragukan dan setelah dilakukan terapi bermain puzzle di dapatkan tingkat kategori perkembangan sesuai usia.

Berdasarkan Literatur review dari kelima artikel didapatkan hasil dari 5 artikel 2 artikel yang menggunakan intrumen denver II dan 3 artikel menggunakan intrumen KPSP, artikel 1 dengan uji Wilcoxon nilai $=0,000$, artikel 2 dengan uji Wilcoxon $=0,002$ artikel 3 dengan menggunakan uji T-test $=0,0001$ artikel 4 dengan uji Wilcoxon $=$ 0,001 dan artikel 5 dengan uji Wilcoxon $=0,046$ uji statistik tersebut menggunakan uji Wilcoxon dan T-test paired. dari hasil tersebut ada pengaruh terapi bermain puzzle untuk perkembangan motorik anak prasekolah. Kedua uji statistic tersebut didapatkan hasil p-value < 0,05 artinya Ho ditolak dan Ha diterima, hasil tersebut menunjukan adanya pengaruh terapi bermain puzzle terhadap perkembangan motorik halus anak prasekolah.

\section{Referensi}

[1] D. Adriana, (2013). "Tumbuh Kembang Dan Terapi Bermain Pada Anak". Jakarta: Salemba Medika.

[2] A. W. N, (2014). "Psikologi Perkembangan Anak Usia Dini". Yogyakarta: Gava Medika.

[3] Astarni, (2017). "diary tumbuh kembang anak". Penerbit Cinta.

[4] Bambang, (2012). "Kembang Anak.Jakarta: Penerbit Buku kedokteran EGC." .

[5] D. A, (2018). "Terapi Bermain Terhadap Kemampuan Motorik Halus Anak Usia prasekolah DiSLB YPPLB, Padang." .

[6] D. A. P. K and M. S. S, "Asep S(2017). "Intervensi Perkembangan Motorik Pada Anak Usia prasekolah".Vol 6 No.2 diambil dari." . 


\section{Prosiding Seminar Nasional Kesehatan Lembaga Penelitian dan Pengabdian Masyarakat Universitas Muhammadiyah Pekajangan Pekalongan}

[7] E. Yuniati, (2018). "influence motorik development smile age of prasekolah.Vol.11No. 1 diambil dari." .

[8] G. D. Graaf, J. J. M. Engelen, A. C. J. Gijsbers, R. Hochstenbach, M. J. V Hoffer, and E. Voorhoeve, (2017). "Estimates Of Live Birth Prevalence OfChildren With Usia prasekolah In The Period 1991-2015 In TheNetherland," J. Intellect. Disabil. Res., vol. 20, no. 7, pp. 1-10.

[9] H. A. A, (2013). "Pengantar ilmu Kesehatan Anak Untuk Pendidikan Kebidanan". Jakarta: Salemba Medika.

[10] L. Triasari, (2019). "Pengaruh Terapi Bermain Terhadap Penigkatan Strategi Koping Dan Penurunan Stress Traumatic Pada Anak Korban Bencana Gempa Bumi Di Kabupaten Lombok Utara Nusa Tenggara Barat". Universitas Airlangga. Diakses dari.

[11] M. all, (2015). "pengaruh pemberian stimulus permainan puzzle terhadap perkembangan motorik halus anak usia 4-6 tahun." .

[12] Muliar, (2016). "The Fine Motor Ability of a Usia prasekolah Student by Playing with Clay at SDLB N 64 SurabayaLubuk Bungsu Kecamatan Agam," vol. 3, no. 1.

[13] Muzamil, (2010). "Upaya Penggunaan Permainan Edukatif Untuk Meningkatkan pemahaman siswa jakarta:balai pustaka." .

[14] Nurkamelia, (2019). "Perkembangan Fisik Motorik Anak Usia Dini vol.2 No.2," Hal, vol. 112-136.

[15] P. S. R, (2016). "Studi Kasus Anak Usia prasekolah. Madiun, Di Akses Dari Jurnal Care Edisi Khusus Tema Ilmiah." .

[16] Ranuh.G S., (2015). "Kembang Anak"," Edisi, vol. 2. 